Unity Journal

Vol. III, 82-96, 2022

Doi: https://doi.org/10.3126/unityj.v3i01.43317

Prithvi Narayan Shah Research Center

Directorate General of Military Training, Nepali Army

Kathmandu, Nepal

\title{
Effectiveness Of Military Diplomacy Towards Nationalism, National Security and Unity
}

\section{Hiranya Lal Lamsal}

\begin{abstract}
Military diplomacy in every country
\end{abstract} strengthens unity, nationalism and national security. It acts as a specific domain of diplomacy that emphasizes primarily on the pursuit of foreign policy interest of the state in the field of security and defence policy, whose actions are associated on the use of negotiations and other diplomatic instruments. Nepal, being a sovereign kingdom, the nation needs a stout military foundation. In this regard, in the field of nationalism, national unity and security, Nepal Army drives its loyalty, obedience, sacrifice and etiquette to maintain common and control in the nation. Considering this fact, this study examines military diplomacy directed to national interest through the perceptions of general people of Rupandehi district, Lumbini Province of Nepal. This study aims at exploring effectiveness of military diplomacy for the well being of the nation and their role to maintain patriotic feeling through national security and unity, and harmonious civil-military relations. To carry out this research, a set of questionnaires was prepared through Google Docs and circulated to general people through emails and messenger. Altogether, 116 participants were taken as population in this study. The snowball sampling technique was used with an online survey tool to collect data. The collected data was analyzed in terms of simple statistical method of percentages. This study found that the effectiveness of military diplomacy for an important security and foreign policy. The result displayed that military diplomacy provides opportunities, security and strength which boosts the national power. It enumerates the activity of military force of the ministry of defense of the nation which conducts a diplomatic scenario to the enforcement of its foreign policy that is of a non-combat nature. It also signifies that military diplomacy marches towards nationalism, which gravitates to build up the interest of obtaining and maintaining the state's sovereignty. Therefore, it is an essential tool for foreign policy at strategic level that adds to raise the degree of nationalism, national security and unity in the state.

Keywords: Diplomacy, military, national security, defence, patriotism

\section{Introduction}

The term 'diplomacy' can be considered an art or practice of performing international harmony. In this paper, military diplomacy implies specific field of diplomacy that can be inferred as a set of activities conducted mainly by the state institutions as well as representatives of the defence department, 
targeted at pursuing the foreign policy interests of the state in the domain of security and defence policy, and whose deeds are based on the use of negotiations and other diplomatic instruments. In addition to this, military diplomacy has been essential constituents of international harmony and an influential methodology to strengthen bilateral and regional relationship, and also to set up close ties with other nations. It represents one of the most significance forms of foreign policy to flourish elegant international relations among the states. Similarly, military diplomacy acts out various types of contributions such as collecting and monitoring of information on the armed forces, upgrading co-operation, communication and mutual relations between the armed forces of the sending and the receiving state.Gupta(2002) addresses diplomacy as an essential element of foreign policy, it targets to receive in adequate transparency and confidence in the military domain and advent a motive towards closer relations with nations through suggestive use of defence. Mihail (2001) discusses the role of military diplomacy which reveals itself in its two basic components i.e., preventive diplomacy and coercive diplomacy. The former is targeted to attain the atmosphere of confidence, essential for the transformation of relations between two states. Relying upon the nature of relations between the states, military diplomacy goes to invent the best motive for the upliftment of military relations. Coercive diplomacy can be undertaken when all the elements of preventive diplomacy are enervated. It addresses the exploitation of the power of ability rather than its real use. It means military power is the pivotal component of coercive diplomacy. Both types of diplomacy strengthen the catchy connections among the nations where the military force aims at identification of the nation by showing its bravery in the stage of the globe.

In the nineteenth century, military diplomacy utterly emphasized on the performance of collecting and evaluating of information on armed forces and on the security situation in the foreign states, with focus on the analysis of present military crisis, challenges and possibilities of military hindrance. The contribution of military diplomats was especially to discover information on events importance from a military point of view such as set of military forts or other military establishment, collect information on the movement of the troops and the military operations implemented by gaining nation with respect to a third country and gather information on specialist publications, official documents and other documents that may have military related information (Vagts ,1967).Military diplomacy in the present scenario is varied from the previous one. It is highly based on present scientific resources and military diplomats. The contemporary practice of diplomacy is basically based on upliftment of co-operation, harmonious relations and smooth communication between the armed forces of the sending and the receiving nation.Furthermore, the collecting and analyzing information on the arm forces and the security condition in the receiving nation as one of the great deeds of military diplomacy (Kleiner, 2010, p.60). The field of military diplomacy generally tends to be minutely connected with the intelligence activities of military efficiency (Pajtinka, 2016, p.1). Thus, military diplomacy appears to characterize as a set of activities conducted mainly by the representatives of the ministry of defence and other state defence authorities along with other state institutions, focused at addressing the foreign policy interests of 
the state in the domain of defence policy and security, whose plans and actions are based on the use of agreement and other diplomatic instruments. For the welfare of the nation and protection from the external and internal threats, military force of the nation performs great contribution. To bring unity and solidarity in the country, diplomacy assists to get reconciliation. Similarly, military training coordination is a necessary attribute of military diplomacy and supports to establish close bonds with other nations of the world. In this regard, the present study is pursuing the Nepalese military diplomacy towards nationalism, national security and unity.

\subsection{Military Diplomacy towards Nationalism, National Security and Unity in Nepal: An Overview}

Military diplomacy provides forces to meet the varied activities undertaken by the Ministry of Defence to dispel hostility establish and maintain trust and support in the development democratically accountable armed forces . Regarding nationalism, national security and unity in Nepal, Military diplomacy has been performing genuine contribution over the centuries. Different nations utilize vary channels of diplomacy which is highly valued to gear up nation's identity, unity and security. Moreover, it is the military diplomacy that safeguards the nationalism and protecting the national sovereignty. In Nepal, it was generally inferred that nation military was set up predominant to the unification of Nepal. The builder of modern Nepal, Prithivi Narayan Shah had played a vital role to It enumerates the activity of military force of the ministry of defense of the nation which conducts a diplomatic scenario to the enforcement of its foreign policy that is of a non-combat nature. It also signifies that military diplomacy marches towards nationalism, which gravitates to build up the interest of obtaining and maintaining the state's sovereignty institutionalize the the military and the modern Nepal. At the time Gorkhali Army was named, it looked very powerful to protect the state. It was very difficult for East India Company forces to face the challenges with Nepali troops .Gorkhali Army who fought bravely against the British and showed great patriotic feelings towards the nations. During the Rana regime, the Prime Minister Chandra Shamsher transformed 'Gorkhali Army' into 'Nepal Army' and later on 'Royal Nepal Army' was addressed by Late King Birendra. After the advent of federal republic democratic in the country, the house of representatives renamed 'Nepal Army' (Acharya, 2009, p. 128.). Though it was named differently in different periods, Military diplomacy had flourished in Nepal from Rana regime, which spanned from 1846 to 1951. First Rana Prime Minister Jung Bahadur Rana campaigned a contingent of Nepali soldiers to aid the British during various wars. During the Rana regime, Nepal Army diplomatically contributed to the British Empire on different occasions. It exhibits military diplomacy as a pivotal procedural for Nepal's diplomatic relations. Nepal Army is well-known for their martial culture in the world. Many of the Nepali troops attended in the Second World War (1939-45) on different fronts very bravely. They exhibited their courageous attitude there which proved that Gorkhali troops sacrificed their life for the sake of their task. Since the past many decades, Nepali military force have shown their dedication towards peace keeping process, identify nation's name and fame; and national security and unity.

Similarly, Nepal accepted an agreement with the US in which American Government 
negotiated to support logistic assistance to the then Royal Nepal Army.Moreover, the British Government also commenced supplying some military aids to Nepal. Nepal and India have been conducting an awarding ceremony of the Army Chiefs of each other the honorable rank of General in recognition of the harmonious relationship between two contires'armies (Amatya, 2018). Yet most importantly, On 14 $14^{\text {th }}$ December, 1955 Nepal has become a member of the United Nations Organization, since then Nepal has been a dynamic and active participant of most UN peace operations. The involvement of the Nepal Army in the UN peace support operations spans a period more than a half century, performing adequate numbers of UN missions. The Nepal Army has renowned as the key contributors to the UN peacekeeping missions. Nepal Army devotion to duty and sensational performance has been broadly acclaimed in the global scenario. In 2020, the Nepali Army has addressed across 12 missions all around the world. Nepal has expected to perform a commitment to serve a number of missions in the coming days(NA Peacekeeping Mission,2020).Nepal's military diplomacy and emerging powers is tremendously sparked by neutrality and nonalignment, that are also the foreign policy goals of Nepal. Nepal army has intently upgraded the portrait of Nepal through the process of UN Peacekeepers. Military campaign not only exercising diplomacy in the arena of the world but also it constructs to identify nationalism along with national unity and security. It is utterly cleared that military diplomacy develops a bond to flourish an elegant diplomatic relations and shows an identity of nationalism in the globe. This study attempts to explore military diplomacy towards national protection, integrity and nationalism as well as the contribution of
Nepal Army in diplomatic relations.

\section{Literature Review}

Diplomacy is the matter of superintending relations among the states. Military diplomacy is a great asset for nationalism, national security and unity in the country. It always plays a pivotal role to maintain national security and nationalism, which is all about an ideology that focuses dedication or servileness to a nation state. To safeguard the state entirely, military's contribution seems significant. In this regard, Nepal Army is performing an outstanding deed for the welfare of the nation. They are generating grand deed to flourish nationalism through diplomatic relations. Besides, to bring integrity in the country, they are co-ordinating various participatory programmes that assist to build unity among the people of the state. Similary, Nepal Army has been undertaking the task diligently in the time of adversity of the people such as natural disasters and other threats. Military force remains stand by to mobilize the troops in the part of national security.Infact national security is commonly conceived as the protection from terrorism, reduce of crime, cyber security, and environmental security and so on. It is a splendid responsibility of the military force to keep its state safe from crisis and hazards. There is a common belief that military diplomacy propels to enhance nationalism, national security and unity in each and every type of the state.

There have been some research studies into the military diplomacy of the state. To review some, Erik (2016) reviewed the military diplomacy and its functions. Based on the analysis of the results of survey among the military diplomats, it is singled out that gathering and analyzing of information on 
the armed forces and the security situation in the receiving state, aimed at pursuing the foreign policy interests of the state in the field of security and defence policy, as relatively the most significant function of the military diplomacy. Similarly, Pankaj (2019) studied military diplomacy and its role in the foreign policy of Nepal and found that the dynamics of Nepalese military diplomacy in three separate periods: during the Rana regime, after the falloff Rana regime and the first dramatic period until the end of monarchical rule. The primary patterns of Nepal military diplomacy have consisted of appeasing its powerful neighbours, balancing one neighbor to another neighbor, implementing non-alignment and internationalism with the United Nations, and keeping equi-proximity with both the neighbors. In addition to this, Willard (2006) conducted military diplomacy: an essential tool for foreign policy at the theater Strategic Level and found that military diplomacy plays an essential role in US diplomatic efforts at the theatre strategic level, carrying tremendous international influence, controlling enormous resources, and capable of quickly executing a wide variety of missions.Muthanna (2011) carried out the paper which provides conceptual and practical aspects of military diplomacy and concluded by stating that nations that evolve and adopt a sound approach to military diplomacy can expect to enjoy a benign, if not completely safe, security environment. These studies guided me in my research concerning exploring the military diplomacy towards national security, unity along with nationalism.

However, military diplomacy brings solidarity and fraternity in the state in order to identify the nation in the global scenario. In this matter, an essay on China's military diplomacy: examination of intentions in foreign strategy (Masuda, 2006) indicated military diplomacy in building mutual understanding atmosphere in foreign strategy. Defence diplomacy: conceptual and practical dimensions with specific reference to South Africa, Strategic review for southern Africa (du Plessis, 2008) exhibited that diplomacy creates specific reference in defense of the state. As these research display, little research has been done on the military diplomacy. Although a few studies have emphasized on military diplomacy in Nepal. It can be notified that there have been not many research works on military diplomacy in the context of Nepal. In this matter, the aim of this study is to explore the effectiveness of military diplomacy towards nationalism, national security and unity in Nepal.

\section{Method}

\subsection{Research Design}

This study was set out to examine the effectiveness of military diplomacy towards nationalism, national security and unity. To attain this objective, this study employed a quantitative survey research design. The survey tool was adapted from the questionnaire. The survey tool was adapted from questionnaires conceptualized by Coteand Miliner (2018), making it suitable to explore military diplomacy towards nationalism, national security and unity, which would assist to examine its effectiveness in Nepal.

\subsection{Participants}

A total of 116 participants were taken as a sample of the population. The snowball sampling technique was used with an online survey tool to collect data as it was not easy due to the fatal pandemic Covid-19 to find potential participants. The total number of 
participants was 116, who are from different places of Rupandehi district of Nepal. In terms of Gender, 76 participants were males while 40 were females. In terms of age group, 80 were below 35 years of age while 5 participants were above 50.Regarding their academic qualifications, most of the participants i.e. 55 held master's degree and 2 M.Phil/PhDs. Similarly, in the employment status, the majority of participants were temporary employees. Regarding the type of job, most of the participants were from teaching sector. This demographic information can be displayed in the following table.

Participant Profile $(\mathrm{N}=116)$

\begin{tabular}{|l|l|l|l|}
\hline Variable & Category & Number & Percentage \% \\
\hline \multirow{5}{*}{ Gender } & Male & 76 & $66 \%$ \\
& Female & 40 & $34 \%$ \\
\hline \multirow{5}{*}{ Age } & Below 35 years & 80 & $69 \%$ \\
& $35-40$ years & 15 & $13 \%$ \\
& $41-45$ years & 10 & $9 \%$ \\
& $46-50$ years & 06 & $5 \%$ \\
& Above 50 years & 05 & $4 \%$ \\
\hline \multirow{5}{*}{ Ecademic qualifications } & Plus-Two/PCL & 9 & $8 \%$ \\
& Bachelor & 50 & $43 \%$ \\
& Master's degree & 55 & $47 \%$ \\
& M.Phil/PhD & 02 & $2 \%$ \\
\hline \multirow{5}{*}{ Job Type } & Permanent & 10 & $9 \%$ \\
& Temporary & 70 & $60 \%$ \\
& Part-Time & 09 & $8 \%$ \\
& Others & 27 & $13 \%$ \\
\hline & Business & 15 & $9 \%$ \\
& Farming & 10 & $34 \%$ \\
& Teaching & 40 & $15 \%$ \\
& Service & 34 & $09 \%$ \\
& Others & & $29 \%$ \\
\hline
\end{tabular}

Source: Online Survey, 2021

\subsection{Data Collection and Analysis Procedures}

The survey questionnaire was executed via Google Docs.It was shared through personal e-mail contacts and via social media networks, asking the respondents to forward it to others. After a week in the field, the web survey absorbed. In this way, the data was collected and analyzed in terms of the simple statistical method of percentages.

\section{Findings}

The present study targeted at exploring the effectiveness of military diplomacy toward nationalism, national security and unity. The following sections exhibit the study results 
delivered through an online survey system utilizing Google Docs in terms of themes with statistical percentage.

\subsection{Diplomacy a tool for Foreign Policy}

Regarding the question on military diplomacy as an essential tool for foreign policy, highest number of respondents accepted it. As evidenced in Table 4.1, the majority of the participants $78 \%$ were in favor of the statement.

Table 4.1 Diplomacy a tool for Foreign Policy

\begin{tabular}{|l|l|l|l|}
\hline \multicolumn{1}{|c|}{ Question } & Yes $\%$ & No $\%$ & Maybe $\%$ \\
\hline $\begin{array}{l}\text { Do you believe military diplomacy as an essential tool } \\
\text { for foreign policy at strategic level? }\end{array}$ & $48 \%$ & $5 \%$ & $47 \%$ \\
\hline
\end{tabular}

Source: Online Survey, 2021

Diplomacy is an essential tool for foreign policy and global governance which implies the wider aims and strategies that show a better path for a state to interaction in the global scenario. Considering this issue, this study observed the effectiveness of military diplomacy for an important security and foreign policy. The result displayed that military diplomacy provides opportunities, security and strength which boosts the national power and it maintains peace, unity and security in the country. It is an essential tool for foreign policy at strategic level.

\subsection{Responsible Safeguard for the Nation}

While going through this issue, most of the respondents opined that military force always stands as a responsible safeguard to maintain security and unity in the state. The responses are stated in Table 4.2 given below.

Table 4.2 Responsible Safeguard for the Nation

\begin{tabular}{|l|l|l|}
\hline $\begin{array}{l}\text { Who do you think the most responsible safeguard for } \\
\text { the state in Nepal? }\end{array}$ & Number & Percentage \% \\
\hline Nepali Politician & 32 & $28 \%$ \\
\hline Nepal Police & 30 & $26 \%$ \\
\hline Military Force & 50 & $43 \%$ \\
\hline Others & 04 & $3 \%$ \\
\hline
\end{tabular}

Source: Online Survey, 2021

Military force of the country has a great contribution to flourish diligent military diplomacy. Military has a capability not only safeguard the state but also protect the nation from different kinds of threats. They assist to maintain peace and stability in the country. Regarding this matter, $43 \%$ respondents responded that military force is the most responsible safeguard for the nation. It indicates that people have great trust towards the military force. 


\subsection{Civil-Military Relations strengthen the Military diplomacy}

A Civil-military relation denotes the relationship between military department and civil society. If they have a good bond that certainly supports in the sector of nationalism and unity. Highest number of respondents strongly agreed that civil-military relations strengthen military diplomacy, which is shown in Table 4.3 below.

Table 4.3 Civil-Military Relations strengthen the Military Diplomacy

\begin{tabular}{|l|l|l|}
\hline $\begin{array}{l}\text { Security and foreign policy are the tools of strengthening } \\
\text { military diplomacy will not be as effective as expected if there } \\
\text { is no effective civil-military relations and synergies between a } \\
\text { country's state security and policy. }\end{array}$ & Number & Percentage\% \\
\hline Strongly Agree & 35 & $30 \%$ \\
\hline Agree & 59 & $51 \%$ \\
\hline Neutral & 10 & $9 \%$ \\
\hline Disagree & 07 & $6 \%$ \\
\hline Strongly Disagree & 05 & $4 \%$ \\
\hline
\end{tabular}

Source: Online Survey, 2021Considering this issue, to strengthen military diplomacy, civilmilitary relations have a genuine connection. The table shows that $51 \%$ respondents have agreed while $31 \%$ agreed strongly. It signifies that security and foreign policy is the instrument of making stout military diplomacy if there is an effective civil-military relation. If there is a good civil-military connections that will be handful for the country progress because it asides peace and fraternity that builds unity among the people of the state.

Table 4.4 Military diplomacy in bilateral or multilateral exercises and in favor of national security and unity

\begin{tabular}{|l|l|l|l|l|l|}
\hline Statement & $\begin{array}{c}\text { Strongly } \\
\text { Agree }\end{array}$ & Agree & Neutral & Disagree & $\begin{array}{l}\text { Strongly } \\
\text { Disagree }\end{array}$ \\
\hline $\begin{array}{l}\text { Military diplomacy paves the way for } \\
\text { participating in bilateral or multilateral } \\
\text { exercises with other countries. }\end{array}$ & $26 \%$ & $50 \%$ & $14 \%$ & $7 \%$ & $3 \%$ \\
\hline $\begin{array}{l}\text { Nepali military force always performs } \\
\text { its activities in favor of national } \\
\text { security and unity. }\end{array}$ & $22 \%$ & $53 \%$ & $16 \%$ & $3 \%$ & $6 \%$ \\
\hline
\end{tabular}

Source: Online Survey, 2021

In Table 4.4, the respondents were asked to agree whether they get agreed that military diplomacy paves the way for participating in bilateral or multilateral exercises with or countries and Nepali military force always performs its activities in favor national security and unity. While going through the responses, in both cases, $50 \%$ respondents have agreed while above $20 \%$ strongly agreed. It shows that military diplomacy decently performs the activities and moves towards the national security and unity by participating in bilateral or multilateral exercise with other countries. That makes strong relations between the countries by maintaining mutual understanding and brotherhood. 


\subsection{Perception towards military force and its diplomacy}

In the domain of national security, military force's role is always pivotal. The diplomacy of military force not only concentrates on security but also assists to flourish nationalism in the global stage. Table 4.5 below shows the highest number of respondents were in favor of military diplomacy.

Table 4.5 Perception towards military force and its diplomacy

\begin{tabular}{|l|l|l|}
\hline $\begin{array}{l}\text { What is your perception towards military force and its diplomacy } \\
\text { in Nepal? }\end{array}$ & Number & Percentage\% \\
\hline $\begin{array}{l}\text { Nepal Army as a precious institution of the state exercising } \\
\text { diplomacy through the process of UN Peace keepers. }\end{array}$ & 81 & $70 \%$ \\
\hline $\begin{array}{l}\text { Nepal Military force doesn't emphasize national security and } \\
\text { unity. }\end{array}$ & 03 & $3 \%$ \\
\hline $\begin{array}{l}\text { Nepal Army isn't performing elegant contribution in the sector of } \\
\text { diplomacy to flourish nationalism in the arena of the world. }\end{array}$ & 20 & $17 \%$ \\
\hline Other & 12 & $10 \%$ \\
\hline
\end{tabular}

Source: Online Survey, 2021

Nepal army as a savior of the nation a precious organization that has been exercising diplomacy through the process of UN peace keepers. In the response of the question perception towards military force and its diplomacy in Nepal, $70 \%$ respondents asserted that Nepali military force is developing diplomacy peace keeping proce.It denotes that Nepal army is doing a fantastic deed to uplift country's identity and nationalism through participating in US peace keeping process which aids a brick in the foundation of military diplomacy.

\subsection{Military diplomacy is effective towards nationalism, national security and unity}

In every country, Military diplomacy strengthens unity, nationalism and national security. It performs as a specific domain of diplomacy that emphasizes primarily on the pursuit of foreign policy interest of the state in the field of security and defense policy, whose actions are associated on the use of negotiations and other diplomatic instruments. In the Table 4.6 which is given below illustrates that highest number of the respondents responded positively regarding the question.

Table 4.6 Military diplomacy is effective towards nationalism, national security and unity

\begin{tabular}{|l|l|l|l|}
\hline Question & Yes $\%$ & No\% & Maybe $\%$ \\
\hline $\begin{array}{l}\text { Do you believe that military diplomacy is effective towards } \\
\text { nationalism, national security and unity in the country? }\end{array}$ & $48 \%$ & $12 \%$ & $40 \%$ \\
\hline
\end{tabular}

Source: Online Survey, 2021

Table 4.6, the respondents were asked to respond about the effectiveness of military diplomacy towards nationalism, national security and unity. $48 \%$ of them responded in their favor which shows that military diplomacy builds up the relations between the nations intently and useful 
to identify nation's name and fame besides performing security in the state. Ultimately, it can be inferred that military force not only set up good diplomatic connections but also it equally contributes to bring unity, nationalism and national security in the country.

Table 4.7 Military diplomacy brings unity and fraternity in the nation

\begin{tabular}{|l|l|l|l|}
\hline Question & Yes $\%$ & No $\%$ & Maybe $\%$ \\
\hline $\begin{array}{l}\text { Do you think military diplomacy brings unity and fraternity in } \\
\text { the nation? }\end{array}$ & $47 \%$ & $8 \%$ & $45 \%$ \\
\hline
\end{tabular}

Source: Online Survey, 2021

Table 4.7 exhibits that $47 \%$ of the respondents viewed that military diplomacy brings unity and fraternity in the nation. It signifies that the diplomacy of the military force always an asset for the nation in order to believe in reconciliation and rapport building.

Table 4.8 Military forces in the establishment of national security and diplomatic relations

\begin{tabular}{|l|l|l|l|}
\hline Question & Yes $\%$ & No\% & Maybe $\%$ \\
\hline $\begin{array}{l}\text { Do you believe that a military force of Nepal has been playing } \\
\text { a genuine role in the establishment of national security and } \\
\text { diplomatic relations? }\end{array}$ & $46 \%$ & $9 \%$ & $45 \%$ \\
\hline
\end{tabular}

Source: Online Survey, 2021

The majority of the respondents $(46 \%)$ asserted that a military force of Nepal has been playing a genuine role in the establishment of national security and diplomatic relations (Table 4.8). What can be obtained from this is that since the past military force of Nepal has performed diligent deed to build rapport between the nations by setting up the national security. It also displays that diplomacy is an essential asset that enhances nationalism and security of the nation.

Table 4.9 Agents contributed for the upliftment of nationalism

\begin{tabular}{|l|l|l|}
\hline $\begin{array}{l}\text { Which of the following agents diplomatically contributed a lot for } \\
\text { the upliftment of nationalism? }\end{array}$ & Number & Percentage\% \\
\hline Nepal Police & 40 & $35 \%$ \\
\hline Military Force & 45 & $39 \%$ \\
\hline Nepali Politician & 20 & $17 \%$ \\
\hline Other & 11 & $9 \%$ \\
\hline
\end{tabular}

Source: Online Survey, $202139 \%$ of the respondents asserted that military force diplomatically contributed for the progress of nationalism (Table 4.9).It can be inferred from this is that military diplomacy has a great effectiveness towards the enhancement of nationalism.

Table 4.10 Military diplomacy addresses national security

\begin{tabular}{|l|l|l|l|}
\hline Question & Yes $\%$ & No $\%$ & Maybe $\%$ \\
\hline Can military diplomacy address national security? & $44 \%$ & $13 \%$ & $43 \%$ \\
\hline
\end{tabular}


Table 4.10 illustrates that military diplomacy addresses the national security in an expected manner. $44 \%$ of the respondents uttered that military diplomacy also connects with the national security .By the assistance of the diplomatic relations, it can preserve the nation from different kinds of threats.

\section{Discussion}

The study results indicate that military diplomacy is moving towards versatile sectors. It goes beyond security and protection of the country against the internal and external challenges, addressed challenges of turmoil and enhances peace that ultimately assists to build rapport and unity in the nation. It has been an essential constituent of international harmony and an influential methodology to strengthen bilateral and regional relationship, and also to set up close ties with other nations. A military force utterly connects with the nationalism as well .The present study exhibits that military diplomacy genuinely focuses on the pursuit of foreign policy along with the national security. In addition to this, in the context of national security, military force's role is always pivotal. The diplomacy of military force not only concentrates on security but also assists to flourish nationalism in the global stage.

Regarding military diplomacy, majority of the respondents asserted that a military force of Nepal has been playing a genuine role in the establishment of national security and diplomatic relations. What can be obtained from this is that since the past military force of Nepal has performed diligent deeds to build solidarity between the nations by bolstering the national security. It demonstrates that diplomacy is an essential asset that enhances nationalism and security of the nation. The responses of the participants also signify that military diplomacy of Nepal propels the external challenges and threats of the state.Similarly, in the response of the question perception towards military force and its diplomacy in Nepal, highest number of respondents asserted that Nepali military force is developing diplomacy through peace keeping process. It shows that the Nepal army is doing a fantastic task to enhance country's identity and nationalism by participating in UN peace keeping process which adds a milestone in the foundation of military diplomacy.

This study is different from the previous studies as cited above (e.g. Masuda, 2006; du Plessis, 2008 \& Muthanna, 2011) in that all the other studies reflect generally military diplomacy of China, South Africa and conceptual and practical aspects of military diplomacy and concluded by stating that nations that evolve and adopt a sound approach to military diplomacy, but this study explored the effectiveness of military diplomacy towards nationalism, national security and unity. It demonstrated that military diplomacy is essential 1 to upgrade the nationalism of the country besides its security and unity .Diplomacy brings unity and solidarity among the people in the nations which finally assists to maintain peace and welfare in the country. Therefore, it can be inferred that the diplomacy of the military force is an asset of every nation. Hence, the present study is highly significant.

Nevertheless, this study attempts to overcome some limitations.Intially, data were collected through snowball sampling, which could not be as representative as it should have been to cover the target population. Secondly, the responses were delivered only from those who had 
access to the internet. Finally, this questionnaire adopted a digital Google Docs format for the survey requesting respondents to response via e-mail and Google form pattern.

\section{Conclusion}

The study has surveyed the effectiveness of military diplomacy towards nationalism, national security and unity in Nepalese context. The domain of military diplomacy not only associates with foreign policy but also signifies the identification of the nation and its security. It exhibits that military diplomacy strengthens unity, nationalism and national security. It performs as a specific domain of diplomacy that emphasizes primarily on the pursuit of foreign policy interest of the state in the field of security and defense policy, whose actions are associated on the use of negotiations and other diplomatic instruments. Although the contemporary practice of diplomacy is basically based on upliftment of co-operation, harmonious relations and smooth communication between the armed forces of the sending and the receiving nation, it is pivotal for the national security, nationalism and unity.

This study found military diplomacy to be essential for security and foreign policy. The result displayed that military diplomacy provides opportunities, security and strength which boosts the national power. It enumerates the activity of military force of the ministry of defense of the nation which conducts a diplomatic scenario to the enforcement of its foreign policy that is of a non-combat nature. It also signifies that military diplomacy marches towards nationalism, which gravitates to build up the interest of securing and maintaining the state's sovereignty. Therefore, the present study implies that military force is an effective organization to set up appropriate diplomacy for the foreign policy of the state and for the identification of the nation with good security and unity. The effectiveness of military diplomacy towards Military-Civil relations can be an area for further research.

\section{References}

Acharya, N. (2009).The Nepalese Army .In Sapkota B (Eds).The Nepalese Security Sector: An almanac. Hungary: Brambauer Publishing.

Aatya, K. (2018). Nepal's Military Diplomacy. The Diplomat. http://thediplomat.com/2018/09Nepalsmilitary-diplomacy/

Cottey, A. (2004).Reshaping Defence Diplomacy: New Roles for Military Cooperation and Assistance. Oxford Universary press, New York.

du Plessis, A. (2008).Defence Diplomacy: Conceptual and Practical Dimensions with Specific Reference to South Africa, Strategic Review for Southern Africa, no.2.

Government of Nepal. (2016). National Security Policy. Ministry of Defense Website .Kathmandu. Singhadurbar.www.mod.gov.np

Gupta, N. (2002). It pays to be coercive. The Indian Express.

Kleiner, J. (2010).Diplomatic Practice. Between Tradition and Innovation. World Scientific Publishing, Singapore.

Kohan, H. (2019).Nationalism. Encyclopedia Britannica. 
Matsuda, Y. (2006). An Essay on China's Military Diplomacy: Examination of Intention in Foreign Strategy, NIDS Security Reports.

Miehs, C. (2001).Topical Military Diplomacy http://www.presamil.ro/VA/3- 4/leng.htm.

Muthanna, K. (2011).Military Diplomacy. Journal of Defence Studies, 5(1).

NA Peace Keeping Mission (2020). The Nepal Army in UN Peace Support Cooperation. http://www. nepalarmy.mil.np/

Pajtinka, E (2016). Military Diplomacy and its Present Functions. Security Dimensions. International and National Studies, pp.179-194.10.24356/SD/20/9.

Vagts, A. (1967).The Military Attache. Princeton University Press, New Jersey.

\section{Questionnaire}

https://docs.google.com/forms/d/1cXwZA9YLllseWSwQFq8iSjKiKpLKhY2SDPKEEHiiJtc/edit

\section{Appendix}

\section{Online Survey Result}

Participant Profile $(\mathrm{N}=116)$

\begin{tabular}{|l|l|l|l|}
\hline Variable & Category & Number & Percentage \% \\
\hline \multirow{2}{*}{ Gender } & Male & 76 & $66 \%$ \\
& Female & 40 & $34 \%$ \\
\hline \multirow{5}{*}{ Age } & Below 35 years & 80 & $69 \%$ \\
& 35-40 years & 15 & $13 \%$ \\
& $41-45$ years & 10 & $9 \%$ \\
& $46-50$ years & 06 & $5 \%$ \\
& Above 50 years & 05 & $4 \%$ \\
\hline \multirow{5}{*}{ Academic qualifications } & Plus-Two/PCL & 9 & $8 \%$ \\
& Bachelor & 50 & $43 \%$ \\
& Master's degree & 55 & $47 \%$ \\
& M.Phil/PhD & 02 & $2 \%$ \\
\hline \multirow{5}{*}{ Job Type } & Permanent & 10 & $9 \%$ \\
& Temporary & 70 & $60 \%$ \\
& Part-Time & 09 & $8 \%$ \\
& Others & 27 & $23 \%$ \\
\hline & Business & 15 & $13 \%$ \\
& Farming & 10 & $9 \%$ \\
& Teaching & 40 & $34 \%$ \\
& Service & 17 & $15 \%$ \\
& Others & 34 & $29 \%$ \\
\hline
\end{tabular}

\begin{tabular}{|l|l|l|l|}
\hline \multicolumn{1}{|c|}{ Question } & Yes $\%$ & $\mathrm{No} \%$ & Maybe $\%$ \\
\hline $\begin{array}{l}\text { Do you believe military diplomacy as an essential tool for foreign } \\
\text { policy at strategic level? }\end{array}$ & $48 \%$ & $5 \%$ & $47 \%$ \\
\hline
\end{tabular}




\begin{tabular}{|l|l|l|}
\hline Who do you think the most responsible safeguard for the state in Nepal? & Number & Percentage $\%$ \\
\hline Nepali Politician & 32 & $28 \%$ \\
\hline Nepal Police & 30 & $26 \%$ \\
\hline Military Force & 50 & $43 \%$ \\
\hline Others & 04 & $3 \%$ \\
\hline
\end{tabular}

Security and foreign policy are the tools of strengthening military diplomacy will not be as effective as expected if there is no effective civilmilitary relations and synergies between a country's state security and policy.

\begin{tabular}{|l|l|l|}
\hline Strongly Agree & 35 & $30 \%$ \\
\hline Agree & 59 & $51 \%$ \\
\hline Neutral & 10 & $9 \%$ \\
\hline Disagree & 07 & $6 \%$ \\
\hline Strongly Disagree & 05 & $4 \%$ \\
\hline
\end{tabular}

\begin{tabular}{|l|l|l|l|l|l|}
\hline \multicolumn{1}{|c|}{ Statement } & Strongly Agree & Agree & Neutral & Disagree & $\begin{array}{l}\text { Strongly } \\
\text { Disagree }\end{array}$ \\
\hline $\begin{array}{l}\text { Military diplomacy paves the way } \\
\text { for participating in bilateral or } \\
\text { multilateral exercises with other } \\
\text { countries. }\end{array}$ & $26 \%$ & $50 \%$ & $14 \%$ & $7 \%$ & $3 \%$ \\
\hline $\begin{array}{l}\text { Nepali military force always performs } \\
\text { its activities in favor of national } \\
\text { security and unity. }\end{array}$ & $22 \%$ & $53 \%$ & $16 \%$ & $3 \%$ & $6 \%$ \\
\hline
\end{tabular}

\begin{tabular}{|l|l|l|}
\hline $\begin{array}{l}\text { What is your perception towards military force and its diplomacy in } \\
\text { Nepal? }\end{array}$ & Number & Percentage $\%$ \\
\hline $\begin{array}{l}\text { Nepal Army as a precious institution of the state exercising diplomacy } \\
\text { through the process of UN Peace keepers. }\end{array}$ & 81 & $70 \%$ \\
\hline Nepal Military force doesn't emphasize national security and unity. & 03 & $3 \%$ \\
\hline $\begin{array}{l}\text { Nepal Army isn't performing elegant contribution in the sector of } \\
\text { diplomacy to flourish nationalism in the arena of the world. }\end{array}$ & 20 & $17 \%$ \\
\hline Other & 12 & $10 \%$ \\
\hline
\end{tabular}

\begin{tabular}{|l|l|l|l|}
\hline Question & Yes $\%$ & No $\%$ & Maybe $\%$ \\
\hline $\begin{array}{l}\text { Do you believe that military diplomacy is effective towards } \\
\text { nationalism, national security and unity in the country? }\end{array}$ & $48 \%$ & $12 \%$ & $40 \%$ \\
\hline
\end{tabular}

\begin{tabular}{|l|l|l|l|}
\hline Question & Yes $\%$ & No $\%$ & Maybe $\%$ \\
\hline $\begin{array}{l}\text { Do you think military diplomacy brings unity and fraternity in the } \\
\text { nation? }\end{array}$ & $47 \%$ & $8 \%$ & $45 \%$ \\
\hline
\end{tabular}




\begin{tabular}{|l|l|l|l|}
\hline Question & Yes $\%$ & No $\%$ & Maybe $\%$ \\
\hline $\begin{array}{l}\text { Do you believe that a military force of Nepal has been playing a genuine } \\
\text { role in the establishment of national security and diplomatic relations? }\end{array}$ & $46 \%$ & $9 \%$ & $45 \%$ \\
\hline
\end{tabular}

\begin{tabular}{|l|l|l|}
\hline $\begin{array}{l}\text { Which of the following agents diplomatically contributed a lot for the } \\
\text { upliftment of nationalism? }\end{array}$ & Number & Percentage $\%$ \\
\hline Nepal Police & 40 & $35 \%$ \\
\hline Military Force & 45 & $39 \%$ \\
\hline Nepali Politician & 20 & $17 \%$ \\
\hline Other & 11 & $9 \%$ \\
\hline
\end{tabular}

\begin{tabular}{|l|l|l|l|}
\hline Question & Yes $\%$ & No $\%$ & Maybe $\%$ \\
\hline Can military diplomacy address intently national security? & $44 \%$ & $13 \%$ & $43 \%$ \\
\hline
\end{tabular}

